\title{
EXPERIMENTAL STUDY OF WOOD GAS-OPERATED POWER PLANT OPERATION
}

\author{
Yaroslav Yarosh ${ }^{1}$, Gennadii Golub ${ }^{2}$, Saveliy Kukharets ${ }^{1}$, Viacheslav Chuba ${ }^{1,2}$ \\ ${ }^{1}$ Zhytomyr National Agroecological University, Ukraine; \\ ${ }^{2}$ National University of Life and Environmental Sciences of Ukraine, Ukraine \\ yaroslav.yarosh76@gmail.com, gagolub@ukr.net, saveliy_76@ukr.net,vvchuba@ukr.net
}

\begin{abstract}
In the power supply system, an important place belongs to autonomous power systems. Considering the need to reduce greenhouse gas emissions and the use of renewable energy sources, the primary source of energy in an autonomous power system can be a wood gas generator. The fuel for such a generator is biomass. The wood gas enters the internal combustion engine, which drives a synchronous generator. The resulting electrical energy is supplied to the consumer. The article presents an experimental plant for generating electric energy on the basis of wood gas, and provides the results of studies in the effect of the used power of the synchronous generator on the gasifier fuel consumption and the amount of gas produced by it. The experimental plant contained a downdraft gasifier, the feature of which is that the combustion and recovery zones have the same diameter. The gasifier was equipped with gas purification filters and a gas cooler. The resulting gas was supplied to the internal combustion engine through a special mixer equipped with the air supply control valve. A synchronous generator was used to convert the mechanical energy of the engine into electrical energy. As the engine and electric generator petrol-electric AC set AB-4-T/400-M1 was taken. The petrol-electric set has a rated power of $4 \mathrm{~kW}$ and produces a three-phase current with a voltage of $220 \mathrm{~V}$. During operation of an experimental gas-operated plant, the growth of the consumed electric power by 12 times causes the linear growth of gasoline consumption by 1.59 times and air consumption by 1.63 times. During the operation of the wood gasoperated experimental plant, an increase in electrical power consumption by 9.5 times causes a linear increase in gas consumption by 2.14 times and air consumption by 1.38 times. The cost of the generated electricity when using wood gas is 2.4 times less than when using gasoline.
\end{abstract}

Keywords: wood gas, gasifier, electric load, air, gasoline.

\section{Introduction}

One of the promising ways to reduce greenhouse gas emissions is the use of biological fuels [1]. Equipment [2], in which biomass is used to produce heat and electricity, is widely used. However, when burning plant biomass, there are difficulties associated with heterogeneity of biomass, relatively high humidity, low specific energy, and low ash melting point. Therefore, the use of a gasifier $[3 ; 4]$ will be appropriate to obtain a stable supply of energy to the consumer when burning plant biomass. Wood gas is used as fuel for internal combustion engines [5], gas turbines [6], thermal equipment [7] and power generation [8].

Considerable attention is paid to the theoretical study of the influence of structural [9] or technological [10] parameters of gasifiers on the quality of the obtained gas. The influence of gasifier components on the quality of the produced gas is being studied [11]. A number of studies [12] substantiate the qualitative composition of wood gas made from wood biomass, biomass of agricultural origin, and coal for the percentage of combustible gases. The influence of such parameters as the operating temperature in the oxidation and reduction zones [13], biomass moisture [12], and the air supply mode [14;15] on the qualitative composition of the obtained gas is substantiated.

Improving the efficiency of the gas production process is also achieved by selecting the mode of air supply to the gas formation chamber $[16 ; 17]$. The internal combustion engine has a significant impact on the air supply to the gas formation chamber [18]. And the mode of operation of the engine, in turn, is affected by the load mode of the electric generator [19].

In addition to ensuring environmental and energy indices, it is important to consider the economic feasibility of switching to the use of a biomass gasifier as an alternative energy source. In addition, the design of the autonomous power supply system based on the gasifier should be reliable, technological, easy to operate and maintain. Therefore, the establishment of rational design parameters of gasifiers, the optimal parameters of the autonomous system and their experimental study is a crucial task. And the purpose of the presented work is to study the effect of the used power of the synchronous generator on the gasifier fuel consumption and the amount of gas produced by it. 


\section{Materials and methods}

An experimental plant was used to conduct the studies (Fig. 1). The experimental plant components (Fig. 2) contained a downdraft gasifier GG-1, the feature of which is that the combustion and recovery zones have the same diameter. This design feature makes it possible to increase the efficiency of the gasification process using the same type of fuel, such as wood, by $15 \%$ compared to similar gasifiers [4]. The height of the recovery zone of the gasifier was $115 \pm 2 \mathrm{~mm}$ with a diameter of $200 \mathrm{~mm}$, the ratio of the height of the recovery zone to the diameter was 0.625 .

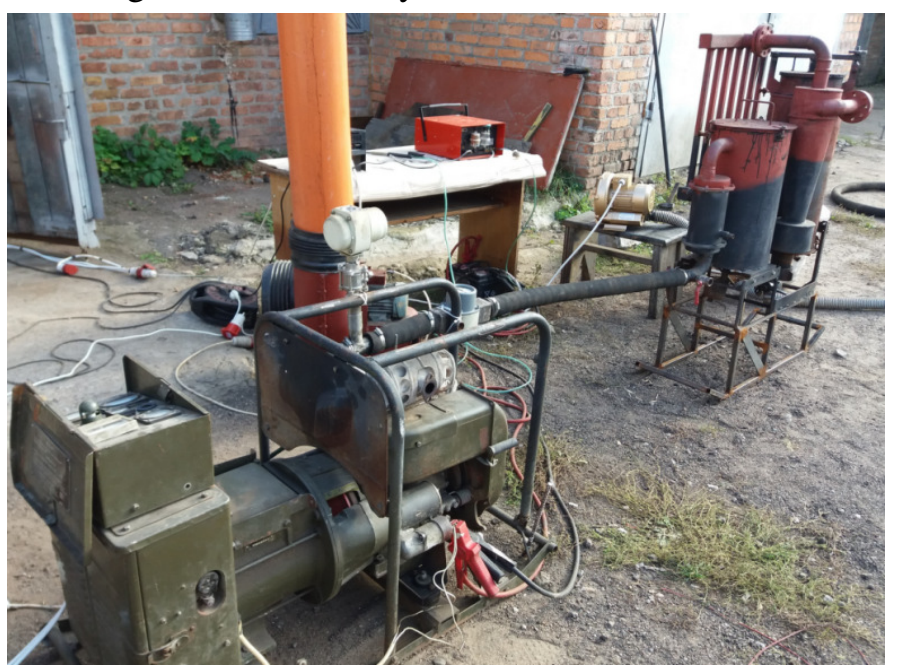

Fig. 1. Exterior of experimental plant

The gas generator was loaded with solid wood fuel in the form of cubic elements with a side of $40 \mathrm{~mm}$.

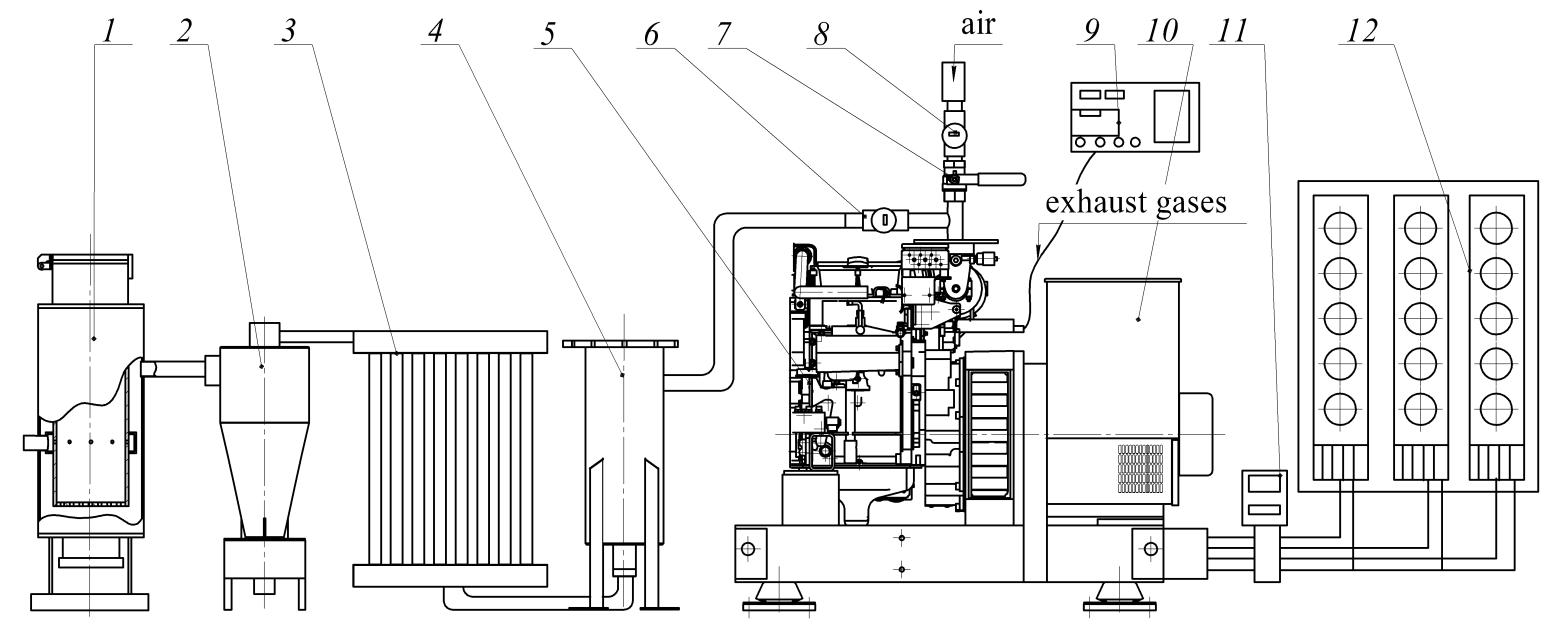

Fig. 2. Scheme of experimental plant: 1 - gasifier; 2 - coarse gas filter; 3 - gas cooler; 4 - fine gas filter; 5 - internal combustion engine; 6 - gas meter; 7 - mixer with the air supply control valve; 8 - air meter; 9 - gas analyzer; 10 - 3-phase electric generator; 11 - device for measuring the current consumption parameters; 12 - load

The downdraft gasifier provides stable supply of energy to the consumer due to the development of the two-stage process of the thermochemical conversion of wood biomass. During the first step of thermochemical conversion (gasification) wood fuel is converted into combustible gaseous components - $\mathrm{CO}$ (17-22 vol. \%), $\mathrm{H}_{2}(16-20 \%)$, small traces of $\mathrm{CH}_{4}(2-3 \%)$ and $\mathrm{CO}_{2}(10-15 \%)$. The next step of thermochemical conversion - combustion of the produced wood gas is provided in the engine.

The gasifier was equipped with gas purification filters and a gas cooler. The resulting gas was supplied to the internal combustion engine through a special mixer equipped with the air supply control valve. The volumes of fuel and air consumed by the engine were recorded using rotary meters 
G-6-RL. A synchronous generator was used to convert the mechanical energy of the engine into electrical energy. As the engine and electric generator petrol-electric AC set AB-4-T/400-M1 was taken. This set was equipped with a two-cylinder engine UDA-25G, which develops a rated power of $5.9 \mathrm{~kW}$ at $3000 \mathrm{rpm}$ crankshaft. The petrol-electric set has a rated power of $4 \mathrm{~kW}$ and produces threephase current with a voltage of $220 \mathrm{~V}$.

For the load of the electric generator, a stand (Fig. 3) was designed. The stand consisted of three blocks, each equipped with five light bulbs of $200 \mathrm{~kW}$ each. The units were connected to the gasifier in phase, the parameters of each phase were controlled by a digital measuring device SocomecDiris A20 (Fig. 2, number 10).

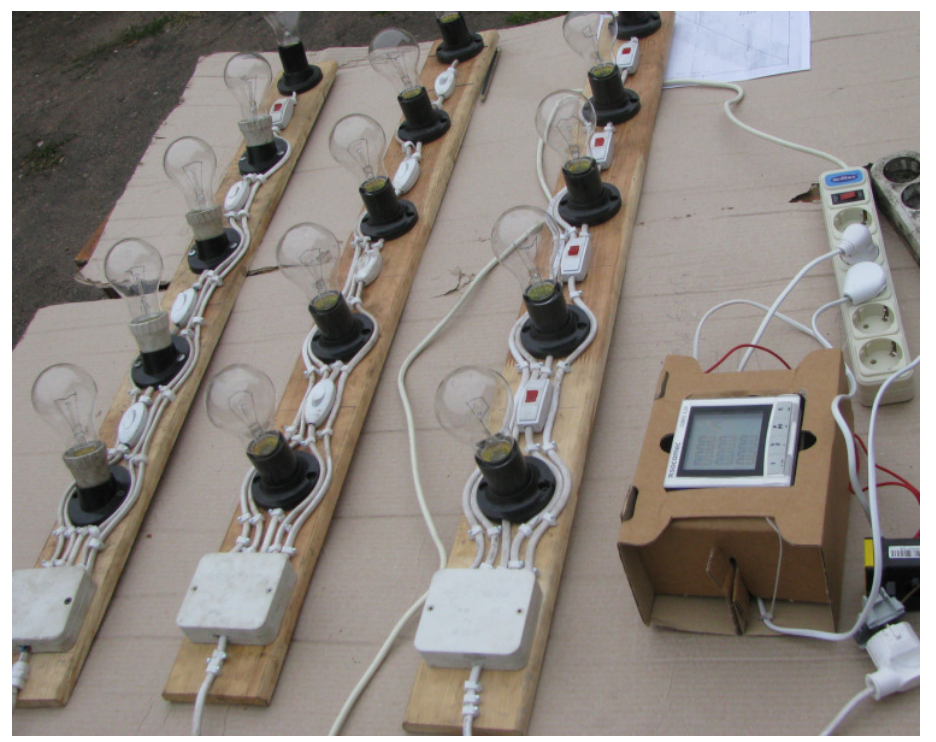

Fig. 3. Load simulating stand

Gasoline consumption was recorded using weights, wood consumption was calculated according to the amount of the gas obtained, based on the specific output of $3 \mathrm{~m}^{3}$ of gas from one kilogram of wood [4].

To measure the concentration of $\mathrm{CO}$ and $\mathrm{CH}$ in the exhaust gases of the electric plant engine a gas analyzer Infrakar-M2T was used.

Every experiment was conducted thrice. The average results are shown in the Table 1. Mandatory randomization was used to reduce the experiment error.

\section{Experimental research results}

Table 1

\begin{tabular}{|c|c|c|c|c|}
\hline \multicolumn{5}{|c|}{ Analysis of the results of the gasoline-operated experimental plant } \\
\hline \multirow{2}{*}{$\begin{array}{l}\text { Electric power } \\
\text { produced, } k W\end{array}$} & \multirow{2}{*}{$\begin{array}{c}\text { Gasoline consumption, } \\
\mathrm{g} \cdot \mathrm{min}^{-1}\end{array}$} & \multirow{2}{*}{$\begin{array}{l}\text { Air consumption, } \\
\mathbf{m}^{3} \cdot \mathbf{m i n}^{-1}\end{array}$} & \multicolumn{2}{|c|}{ Emissions of } \\
\hline & & & CO, \% & $\mathrm{CH}, \mathrm{mln}^{-1}$ \\
\hline 0 & 21.43 & 0.21 & 8.22 & 170 \\
\hline 0.25 & 24.66 & 0.22 & 8.12 & 171 \\
\hline 0.50 & 26.28 & 0.22 & 8.05 & 170 \\
\hline 0.77 & 26.87 & 0.24 & 7.84 & 170 \\
\hline 1.00 & 28.13 & 0.24 & 7.87 & 172 \\
\hline 1.23 & 29.03 & 0.26 & 7.84 & 173 \\
\hline 2.01 & 33.33 & 0.30 & 7.69 & 192 \\
\hline 2.20 & 34.62 & 0.32 & 7.61 & 198 \\
\hline 2.42 & 35.36 & 0.33 & 7.60 & 210 \\
\hline 2.70 & 37.50 & 0.33 & 7.70 & 230 \\
\hline 2.97 & 39.26 & 0.35 & 7.78 & 245 \\
\hline
\end{tabular}


Table 1 (continued)

\begin{tabular}{|c|c|c|c|c|}
\hline \multicolumn{5}{|c|}{ Analysis of the results of the wood gas-operated experimental plant } \\
\hline \multirow{2}{*}{$\begin{array}{l}\text { Electric power } \\
\text { produced, } k W\end{array}$} & \multirow{2}{*}{$\begin{array}{l}\text { Gas consumption, } \\
\mathrm{g} \cdot \mathrm{min}^{-1}\end{array}$} & \multirow{2}{*}{$\begin{array}{l}\text { Air consumption, } \\
\mathbf{m}^{3} \cdot \mathbf{m i n}^{-1}\end{array}$} & \multicolumn{2}{|c|}{ Emissions of } \\
\hline & & & $\mathrm{CO}, \%$ & $\mathrm{CH}, \mathrm{mln}^{-1}$ \\
\hline 0 & 0.150 & 0.180 & 0.130 & 38 \\
\hline 0.24 & 0.174 & 0.182 & 0.130 & 35 \\
\hline 0.49 & 0.200 & 0.184 & 0.135 & 32 \\
\hline 0.76 & 0.230 & 0.188 & 0.140 & 30 \\
\hline 0.98 & 0.250 & 0.192 & 0.140 & 27 \\
\hline 1.20 & 0.276 & 0.197 & 0.145 & 25 \\
\hline 1.71 & 0.324 & 0.219 & 0.150 & 25 \\
\hline 2.091 & 0.358 & 0.238 & 0.160 & 26 \\
\hline 2.25 & 0.372 & 0.252 & 0.165 & 27 \\
\hline
\end{tabular}

Verification of reproducibility of the experiments was carried out according to the Cochran criterion [20].

\section{Results and discussion}

Analysis of the results of the gasoline-operated experimental plant in graphical form is shown in Fig. 4.

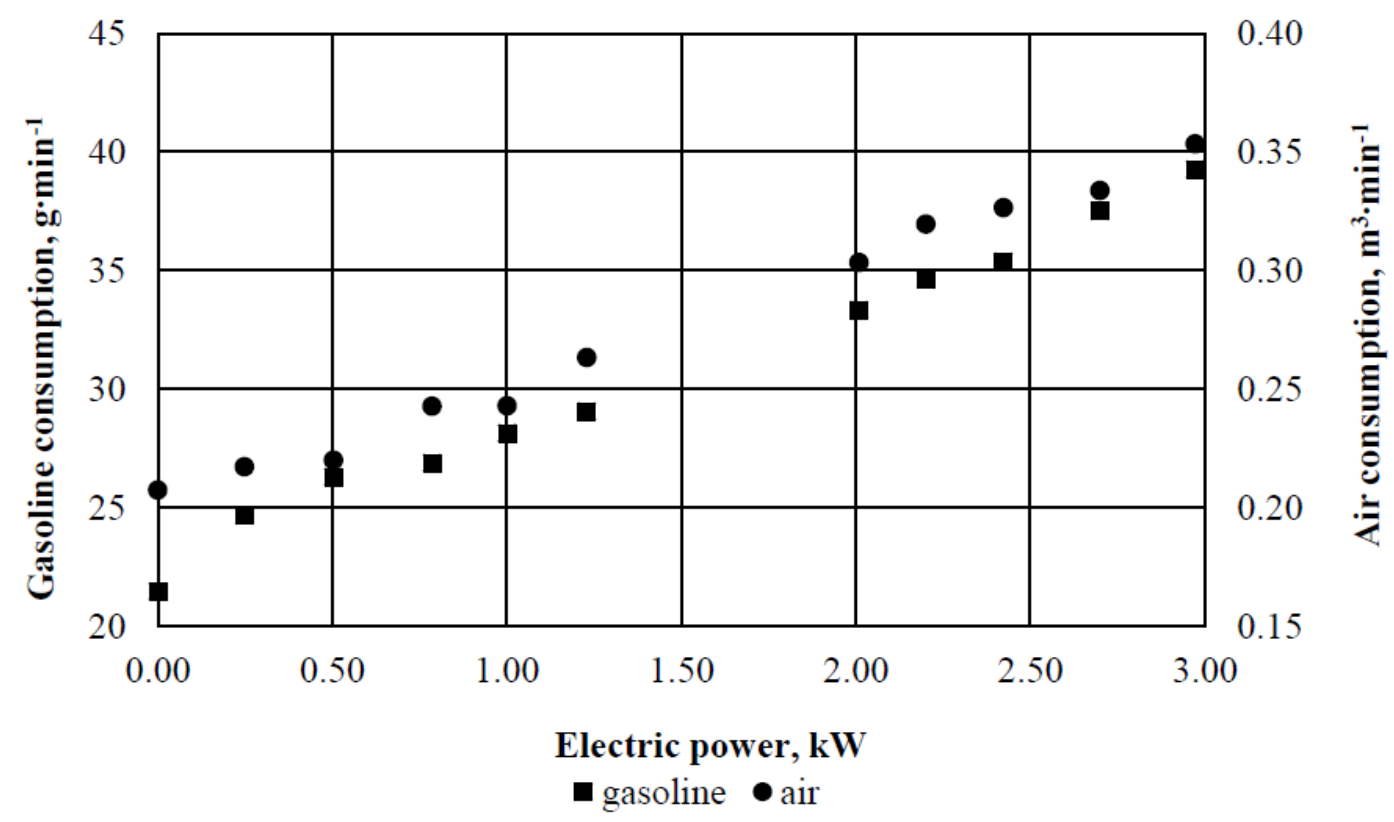

Fig. 4. Gasoline and air consumption depending on power consumption

From the graph analysis, Fig. 4, it occurs that with the growth of electric power consumption by 12 times (from 0.25 to $2.97 \mathrm{~kW}$ ), there is a linear increase in gasoline consumption by 1.59 times (from 25 to $39 \mathrm{~g} \cdot \mathrm{min}^{-1}$ ) and in air consumption by 1.63 times (from 0.217 to $0.353 \mathrm{~m}^{3} \cdot \mathrm{min}^{-1}$ ).

The analysis of the wood gas-operated experimental plant operation in graphical form is shown in Fig. 5.

The graph analysis in Fig. 5 shows that with the growth of electric power consumption by 9.5 times (from 0.24 to $2.25 \mathrm{~kW}$ ), there is a linear increase in gas consumption by 2.14 times $(0.174$ to $0.372 \mathrm{~m}^{3} \cdot \mathrm{min}^{-1}$ ) and air consumption by 1.38 times (from 0.182 to $0.252 \mathrm{~m}^{3} \cdot \mathrm{min}^{-1}$ ).

Considering that the cost of gasoline is $20 \mathrm{UAH} \cdot 1^{-1}$, and the cost of wood (including the preparation for combustion in the gasifier) is $2.5 \mathrm{UAH} \cdot \mathrm{kg}^{-1}$, the cost of the obtained electricity can be found (Fig. 6). 


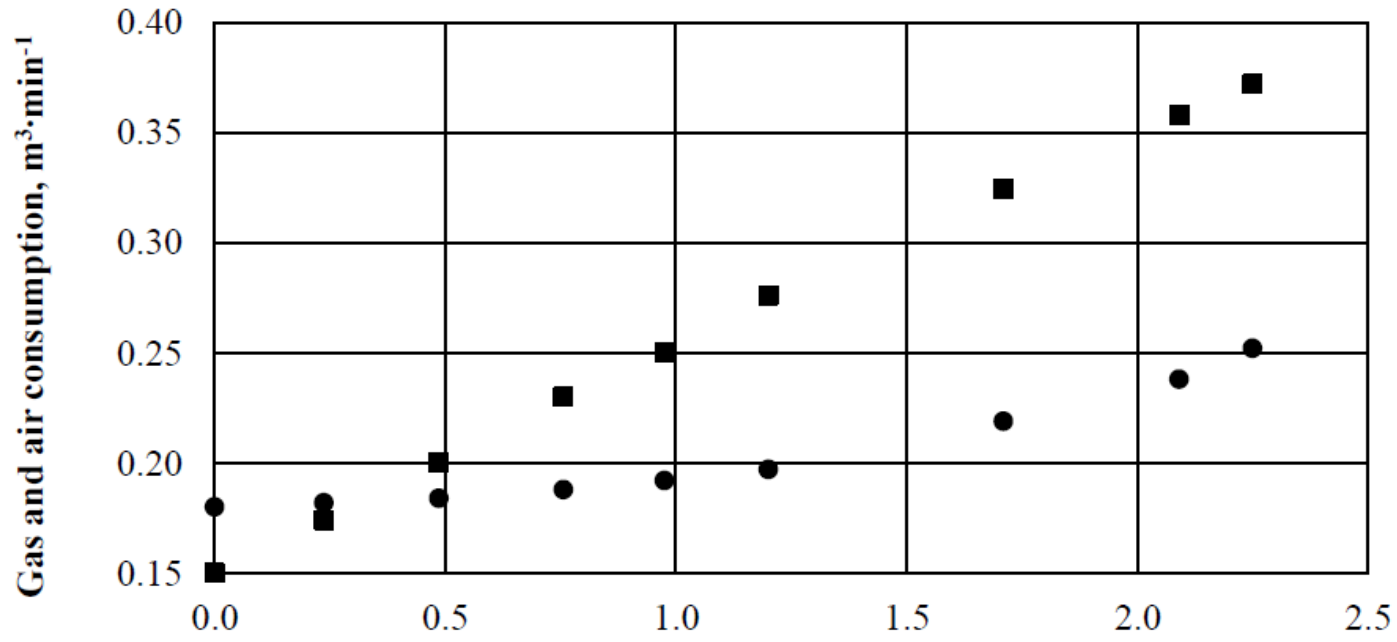

Electric power, $\mathrm{kW}$

wood gas

- air

Fig. 5.Wood gas and air consumption depending on power consumption

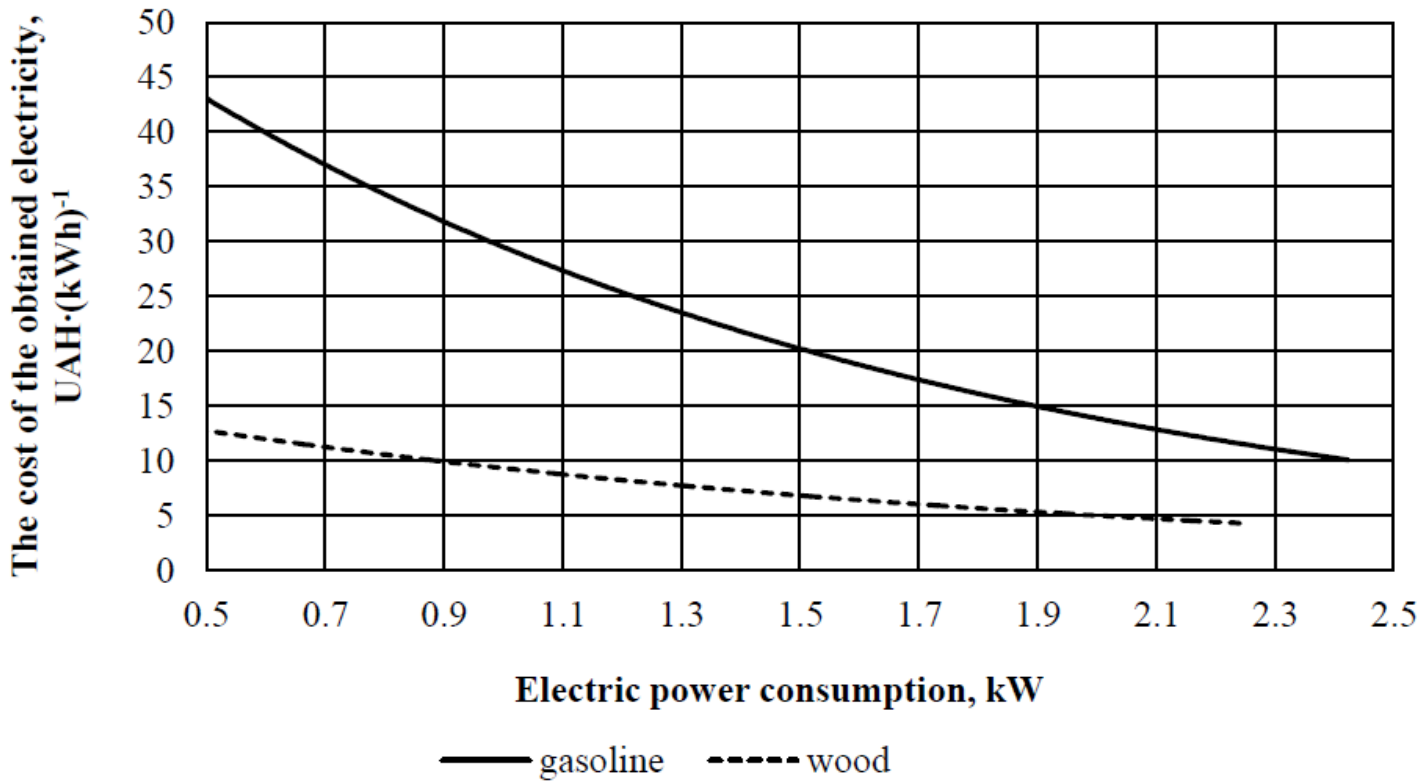

Fig. 6. Cost of produced electricity

The analysis of the graph, Fig. 6, shows that with an increase in the power of the consumer, the cost of the produced electricity decreases and at the power of $2.25 \mathrm{~kW}$ it is $5 \mathrm{UAH} \cdot(\mathrm{kWh})^{-1}$ for gas. For gasoline, the cost of electricity is 2.4 times higher and it is $12 \mathrm{UAH} \cdot(\mathrm{kWh})^{-1}$.

Fig 7 shows the content of $\mathrm{CO}$ and $\mathrm{CH}_{4}$ in the exhaust gases of the gasoline-operated power plant engine. Fig. 8 shows the content of $\mathrm{CO}$ and $\mathrm{CH}_{4}$ in the exhaust gases of the wood gas-operated power plant engine.

The analysis of the graphs shows that with electric power consumption, which corresponds to the nominal load of the electric generator using wood gas as fuel, $\mathrm{CO}$ emissions are reduced by 47 times, and $\mathrm{CH}$ - by 9 times. 


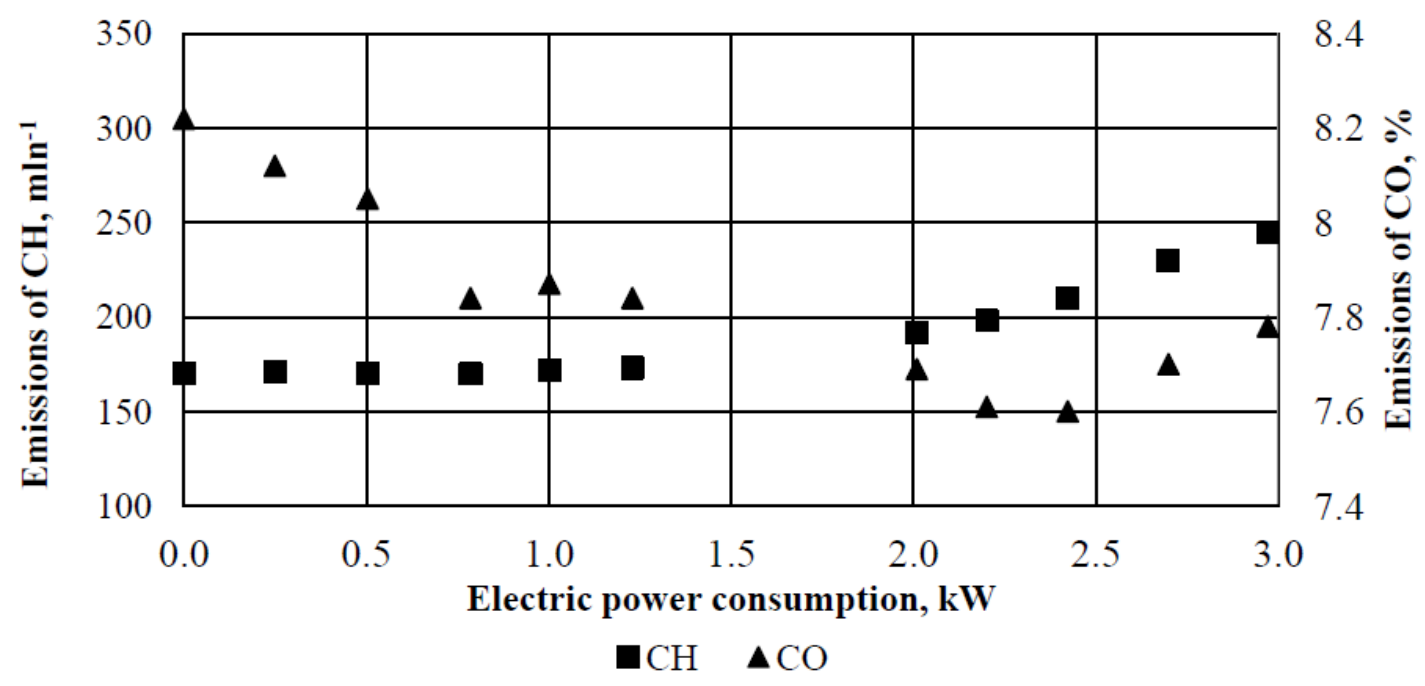

Fig. 7. Content of harmful gases in exhaust gases of gasoline-operated engine

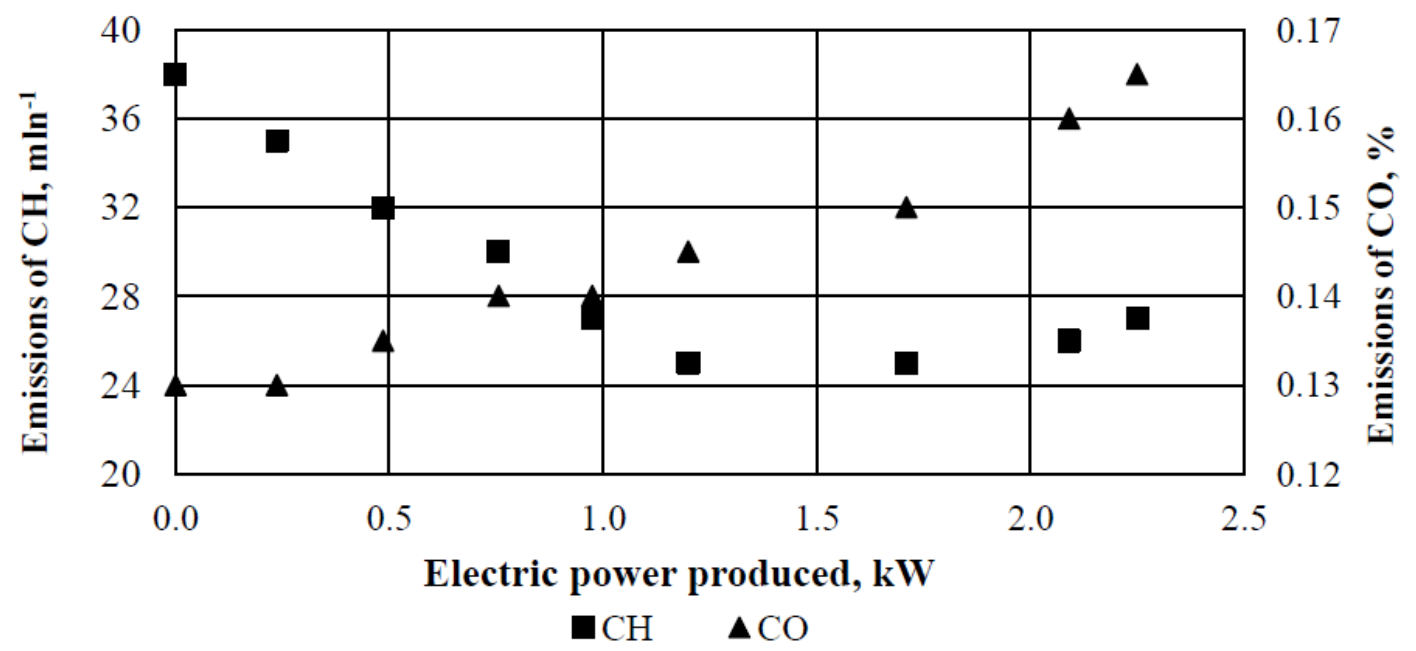

Fig. 8. Content of harmful gases in exhaust gases of wood gas-operated engine

\section{Conclusions}

1. During operation of the gasoline-operated experimental plant, an increase in electric power consumption by 12 times (from 0.25 to $2.97 \mathrm{~kW}$ ) causes a linear increase in gasoline consumption by 1.59 times (from 25 to $39 \mathrm{~g} \cdot \mathrm{min}^{-1}$ ) and air consumption by 1.63 times (from 0.217 to $\left.0.253 \mathrm{~m}^{3} \cdot \mathrm{min}^{-1}\right)$.

2. During operation of the wood gas-operated experimental plant, an increase in electrical power consumption by 9.5 times (from 0.24 to $2.25 \mathrm{~kW}$ ) causes a linear increase in gas consumption by 2.14 times $\left(0.174\right.$ to $0.372 \mathrm{~m}^{3} \cdot \mathrm{min}^{-1}$ ) and air consumption by 1.38 times (from 0.182 to $\left.0.252 \mathrm{~m}^{3} \cdot \mathrm{min}^{-1}\right)$.

3. At consumption of electric power of $2.25 \mathrm{~kW}$ its cost is $5 \mathrm{UAH} \cdot(\mathrm{kWh})^{-1}$ for wood gas.

4. The cost of electricity produced by an autonomous wood gas-operated power plant is 2.4 times lower than for a gasoline-operated power plant.

5. The use of wood gas instead of gasoline in autonomous power plants can significantly reduce emissions of $\mathrm{CO}$ and $\mathrm{CH}$ into the atmosphere.

\section{References}

[1] Melece L., Krievina A. Bioenergy in Latvia: sector value and impacts. Proceedings of 15th International Scientific Conference "Engineering for rural development", May 25-27, 2016, Jelgava, Latvia, pp. 1170-1176. 
[2] Barmina. I., Valdmanis R., Zake M. etc. Development of gasification/combustion characteristics at thermochemical conversion of biomass mixtures. Proceedings of 16th International Scientific Conference "Engineering for rural development", May 24-26, 2017, Jelgava, Latvia, pp. 725-729.

[3] Patra, T. K., Sheth, P. N., Biomass gasification models for downdraft gasifier: A state-of-the-art review. Renewable and Sustainable Energy Reviews, vol. 50, 2015, pp. 583-593.

[4] Golub G., Kukharets S., Tsyvenkova N. etc. Experimental study into the influence of straw content in fuel on parameters of generator gas. Eastern-European Journal of Enterprise Technologies, vol. 5/8 (95), 2018, pp. 76-86

[5] Anukam A., Mamphweli S., Reddy R. etc. Pre-processing of sugarcane bagasse for gasification in a downdraft biomass gasifier system: A comprehensive review. Renewable and Sustainable Energy Reviews, vol. 66, 2016, pp. 775-801.

[6] De Mena B., Vera D., Jurado F. Ortega M. Updraft gasifier and ORC system for high ash content biomass: A modelling and simulation study. Fuel Processing Technology, vol. 156, 2016, pp. 394406.

[7] Katsaros G., Nguyen T.-V. and Rokni M. Tri-generation System based on Municipal Waste Gasification, Fuel Cell and an Absorption Chiller. Journal of Sustainable Development of Energy, Water and Environment Systems, vol. 6(1), 2018, pp. 13-32.

[8] Pérez N. P., Machin E. B., Pedroso D. T. etc. Biomass Gasification for Combined Heat and Power Generation in the Cuban Context: Energetic and Economic Analysis. Applied Thermal Engineering, vol. 90, 2015, pp. 1-12.

[9] Susastriawan A. A. P., Saptoad H., Purnomo. Small-scale downdraft gasifiers for biomass gasification: A review. Renewable and Sustainable Energy Reviews, vol. 76, 2017, pp. 989-1003.

[10] Sheth P. N., Babu B. V. Experimental studies on producer gas generation from wood waste in a downdraft biomass gasifier. Bioresource Technology, vol. 100, iss. 12, 2009, pp. 3127-3133.

[11] Jia J., Abudula A., Wei L. etc. Thermodynamic modeling of an integrated biomass gasification and solid oxide fuel cell system. Renewable Energy, vol. 81, 2015, pp. 400-410.

[12] Channiwala S. A., Ratnadhariya, J. K. Three zone equilibrium and kinetic free modeling of biomass gasifier - a novel approach. Renewable Energy, vol. 34, iss. 4, 2009, pp 1050-1058.

[13] Sharma A.K. Modeling and simulation of a downdraft biomass gasifier 1. Model development and validation. Energy Conversion and Management, vol. 52, 2011, pp 1386-1396.

[14] Melgar A., Perez J., Laget H., Horillo A. Thermochemical equilibrium modelling of a gasifying process. Energy Convers Manage, vol. 48, iss. 1, 2007, pp 56-67.

[15]Zainal Z. A., Ali R., Lean C. H., Seetharamu K.N. Prediction of performance of a downdraft gasifier using equilibrium modeling for different biomass materials. Energy Conversion and Management, vol. 42, iss. 12, 2001, pp 1499-1515.

[16] Cerone N., Zimbardi Fr., Contuzzi L. etc. Air-steam and oxy-steam gasification of hydrolytic residues from biorefinery. Fuel Processing Technology, vol. 167, 2017, pp. 451-461.

[17] Ferreira S. D., Lazzarotto I. P., Junges J. etc. Steam gasification of biochar derived from elephant grass pyrolysis in a screw reactor. Energy Conversion and Management, vol. 153, 2017, pp. 163174.

[18] Pérez N.P., Machin E.B., Pedroso D.T. etc. Biomass gasification for combined heat and power generation in the Cuban context: Energetic and economic analysis. Applied Thermal Engineering, vol. 90, 2015, pp. 1-12,

[19] Centeno F., Mahkamov K., Silva Lora E. etc. Theoretical and experimental investigations of a downdraft biomass gasifier-spark ignition engine power system. Renewable Energy, vol. 37, iss. 1, 2012, pp. 97-108.

[20] Sarker S., Arauzo J., Nielsen H. K. Semi-continuous feeding and gasification of alfalfa and wheat straw pellets in a lab-scale fluidizedbed reactor. Energy Conversion and Management, vol. 99, 2015, pp. 50-61. 